\title{
Level of academic stress for students of guidance and counseling at Semarang State University during the pandemic
}

\author{
Tivanny Octasya* \\ Faculty of Education, Semarang State University \\ email: tivannyoctasya@students.unnes.ac.id \\ Eem Munawaroh \\ Faculty of Education, Semarang State University \\ email: eemmunawaroh@mail.unnes.ac.id
}

Received: April 22, 2021; Revised: April 28, 2021; Accepted: May 30, 2021

\begin{abstract}
Academic stress is a subjective perception of an academic condition or a response experienced by students in the form of negative physical reactions, behaviors, thoughts, and emotions that arise due to school or academic demands. During a pandemic Covid 19 most of earning activities becomes online. The aim of this research is to determine the level of academic stress among students in Guidance and Counseling Department, Semarang State University during the pandemic. The method used is descriptive qualitative research. This research conducted interviews to collect data by using purposive sampling. The results show that students experience symptoms of academic stress symptoms that affect their physical, emotional, behavioral, and thoughts as well as several factors that influence academic stress both in themselves (internally) and in the environment and circumstances (externally). The conclusion of this study is the respondents' stress level is quite high or increases when they get assignments from the lecturers.
\end{abstract}

Keywords: college students, academic stress, pandemic

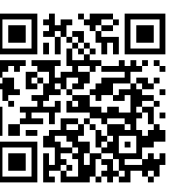

This is an open-access article under the CC-BY-SA license.

\section{Introduction}

At first, the economic world was very much affected by the spread of the corona virus, but at this time the world of education also felt the impact. With this situation, many affected countries took steps to close face-to-face learning activities, including in Indonesia itself, this fact has prompted the government or educational institutions to create an alternative implementation of education for affected students or students who are unable to carry out face-to-face learning directly in class. UNESCO provides data that more than 39 countries closed their educational institutions with the number of students affected by this policy as much 421.388 .462 students both in school and higher education. Consequently, the introduction of the concept of a lesson as applied in is face-to-face learning cannot work well. In is face-to-face learning, there will be the delivery of the learning concept and its objectives first. Then, learning continues until its 
understanding and development. These stages are considered not going well in an emergency situation like now (Charismiadji, 2020).

The stuttering of the educators, the confusion of the parents who accompany their children to study at home, and the students who are confused about online learning methods accompanied by a pile of tasks have caused widespread anxiety, especially during the Covid-19 pandemic. Research conducted by Livana PH et al (2020) shows that learning tasks are a major factor causing student stress during the Covid-19 pandemic. Anxiety affects student learning outcomes because anxiety tends to produce confusion and perceptual distortions. These distortions can interfere with learning by reducing the ability to focus attention, lowering memory, and interfering with the ability to connect one thing to another (Kaplan and Saddock, 2005). The problems experienced by students, if not treated immediately, can lead to more serious psychological problems such as stress. The results of research by Maia, Berta Rodrigues, Paulo César (2020) show that students who were evaluated during the pandemic period showed significantly higher levels of anxiety, depression, and stress, compared to students in normal times. The results show that the pandemic has a negative psychological effect on students.

Based on the results of these preliminary studies, it is necessary to carry out research aimed at knowing the description of Student Academic Stress Levels in the learning process during the Covid-19 pandemic through qualitative research.

\section{A. Stress}

\section{Definition of Stress}

Weinberg and Gould (2003) define stress as "a substantial return between demand (physical and psychological) and response capability, under conditions where failure to meet that demand has importance consequences". This means that there is an imbalance between demands (physical and psychological) and the ability to fulfill them. Failure to meet these needs will have a crucial impact.

Anoraga (in Anggraeni, 2003) argues that stress is a person's response, both physically and mentally to a change in his environment that is felt to be disturbing and causes him to be threatened. Based on the above understanding, stress is a mental disorder faced by a person due to pressure. This pressure arises from the failure of individuals to fulfill their needs or desires. This pressure can come from within, or from outside.

\section{Definition of Academic Stress}

Students who experience academic stress have a maladaptive perception of academic demands ( Nurmalasari et al, 2016) relevant to statement by Alvin (Eryanti, 2012) academic stress is the pressures that occur within students caused by competition and academic demands. In line with this (Taufik, T., \& Ifdil, I. 2013; Muharrifah, A. 2009) explained that academic stress arises when expectations for academic achievement increase, both from parents, teachers, and peers. These expectations are often not in accordance with the abilities possessed by students, causing psychological pressure that affects achievement. Academic stress is stress that is included in the distress category (Rahmawati, W. K. 2017; Adawiyah, R. 2017). Academic stress is a condition in which students cannot face academic demands and perceive academic demands as a nuisance. Academic stress is caused by academic stressors (Sayekti, E. (2017). Academic stressors are stress that originates from the learning process, such as: pressure to go to class, length of study, cheating, lots of tasks, low achievement, decisions to determine majors and career, as well as anxiety when facing exams (Rahmawati, W. K. 2017).

\section{Symptoms of Academic Stress}

Individuals who experience stress will show emotional and physical symptoms (Hernawati, N. 2006; Inayatillah, V. 2015). It is further explained as follows. According to 
(Simbolon, I. 2015; Fahmi, F. 2011) stress symptoms consist of physical, emotional, and behavioral added, further explained as follows: Physical symptoms.

a. Symptoms that fall into the physical category include as follow : headache, palpitations, changes in diet, weakness or weakness, much urination, and difficulty swallowing.

b. Emotional symptoms Students who experience emotional academic stress are characterized by: restlessness or anxiety, sadness or depression due to academic demands, and feel their selfesteem has decreased or feel unable to carry out the demands of education or academics.

\section{Factor Causing Academic Stress}

\section{a. Internal}

1) Mindset. Individuals who think they cannot control the situation, tend to experience greater stress. The greater the control that he can do something, the less likely it is stressed that students will experience. This Pandemic period is a period of transition or transition from being able to meet face to face and lecture directly online and completely online. This situation inevitably has to be accepted by both lecturers and students so that a situation control is needed so that stress does not occur.

2) Personality. The personality of an individual can determine the level of tolerance to stress. The stress levels of optimistic students is usually lower than that of pessimistic individuals. Beliefs. The next internal cause that determines the level of individual stress is beliefs or thoughts about oneself. Self-belief plays an important role in interpreting situations around individuals. The assessment that students believe can change their mindset towards something even in the long term can bring psychological stress. It is important to have an optimistic mindset, especially during a pandemic. As we know, every day we can see information about Covid cases in Indonesia, so that the possibility of stressing is small we must be more optimistic and always be able to be positive.

\section{b. External}

External factors that cause academic stress

1) Lessons are denser. The curriculum in the standard education system is getting higher and higher. As a result, competition is getting tougher, learning time increases, and individual burdens are increasing. Even though some of these reasons are important for the development of education in a country, it cannot be turned a blind eye that it increases the level of stress faced by students. Especially during a pandemic, there must be certain adaptations of the curriculum system so that things like stress can be overcome because of course in a pandemic we have to adjust certain parts to minimize the stress level of each individual who carries out online learning.

2) Pressure to perform high Students are highly pressured to do well on their tests. This pressure mainly comes from parents, family, teachers, neighbors, peers, and yourself.

3) Promotion of social status. Education has always been a symbol of social status. People with high academic qualifications will be respected by society and those without highly educated will be looked down upon. Individuals who are successful Academics are very well-liked, recognized, and praised by the public.

\section{Method}

This type of research used by researchers is descriptive qualitative. According to Sugiyono (2016: 9) qualitative research methods are research methods used to examine the conditions of 
natural objects where the researcher is the key instrument. The research was conducted in the Department of Guidance and Counseling, State University of Semarang. The subjects in this study are referred to as informants or sources. Resource people are individuals in research backgrounds who are used as sources of information needed in collecting research data. There were two sources in this study, namely the Counseling Guidance student with the initials NRS and JR. To determine the sources in this study, the technique used was purposive sampling. Purposive sampling is a data source sampling technique with certain considerations (Sugiyono, 2016: 218). Resource peoplep are those who know best or are most qualified to be sampled.

The data collection method used in this qualitative research is interviews, interviews are conducted with sources in the online process via WhatsApp because it was blocked by the pandemic, so they could not meet face to face, so the remote method was chosen.

\section{Findings and Discussion}

The results of the analysis of interview data from the two sources contained 10 questions related to the factors that influence and also the symptoms of Academic Stress. Based on the results of interviews from two subjects, it is known that they experience symptoms of symptoms in academic stress, both physical, emotional and behavioral. 1) From a physical point of view in the interview, the two informants mentioned that they felt headaches and dizziness that they usually do not feel during offline learning, 2) In terms of emotions, the same informants felt anxious when they got an assignment from the lecturer and the second resource if he feels sad and very bored with this online lecture and their emotions become unstable because sometimes they often cry to get an assignment that they feel unable to do: Question 'Have you ever cried because of assignments or other academic demands?'

N1 : "I have cried, cried because if I cry more because of what, because I haven't been able to properly divide my time, right now. Now it's really like the one that feels really difficult "

N2 : "Often cry, sometimes for example if I do a job and it is difficult, a lot, a lot of people get a task, it's like I feel I can or no, this seems really difficult and very burdensome. I also ask my friends to not continue to work on, for example, if it's a tight time, I just cry. "

3) This ultimately affects student behavior based on the responses or opinions of the two sources. If they get an assignment from a lecturer, both of them have the same opinion that doing it is not as fast as possible. Informant 1 said that he usually worked when he was running on deadlines and this semester was very different from the previous semester because of the increasingly dominant feeling of laziness when studying online. Meanwhile, the second resource person said that the reason he did not do it as quickly as possible was due to the demands of another task, so he had to do other priority tasks first and also sometimes felt lazy and preferred to do other activities: Question 'When you get an assignment, will you do it right away or not?'

N1 : "For me not, hehe. Because, I'm honest this semester I'm the type to work on it right on the deadline if there isn't a deadline it can't be because maybe I already have a lot of interests, like that."

N2: "Usually, if for example, there was a task yesterday that was more tightly packed with deadlines, usually I did the other one first, but for example, there are no other tasks besides that I usually do it right away if I'm not lazy." 


\section{Factors Affecting Academic Stress}

There are two factors that influence academic stress, namely internal factors and external factors. 1) Internal factors, namely factors that come from within the student itself or can be said to be a factor that is the control of the student. Even though they feel that the task is very heavy, feel unable to do it, and do it when it reaches the deadline, the control of these two students is quite good, such as the results of the interview obtained as follow: Question 'Have you ever felt unable to do the assigned task?'

NS 1: I have, but I can't just stop doing my assignments. I tried to ask this to my friends like this, how do you keep trying to see yours so that there are references like that and in the end you still do it as much as possible, it won't be done like that. The important thin is that there is an effort.

NS2: "If don't understand, I ask a friend"

From this we can see that they both of have good self-control in terms of doing tasks even though at the beginning there are many obstacles and make their emotions unstable. 2) For external factors themselves, namely from the environment or the current situation and support from both parents. As we know, with a pandemic like this, it requires all of us to be at home, not only a matter of studying but also of other activities. From the results of interviews related to questions related to the pandemic, informant 1 said that online lectures were very effective because when online NS1 said they did not really understand the material that was often delivered, and felt bored and tired and the workload was heavier than face-to-face lectures, while things Others such as limited quota also greatly affect him. Not much different from what was conveyed by NS 2 , he also said that he felt that online lectures were ineffective but could only follow because the condition of Covid-19 had not subsided. From other factors such as parents, both of their parents tend to be more worried because they see their children behind the laptop too long, and sometimes it is too late to eat because they do assignments: Question 'How do parents respond and family respond when they see you all day in front laptop or cellphone for online lecture?

NS 1: The response from my parents was yes, always asking how come they keep on asking, how come the conditions are like this, right? We are burdened with many tasks

NS2 : Sometimes what is it like they say how come you go to college like there's no stopping, also on Saturday that week you were doing your assignments, thought you were also in college, right? Until there wasn't like a holiday at all. So it's like resting first, eat first then you get sick. What if I do, for example, if I do my assignments, sometimes I don't take a bath like the time is not too bad, sometimes I don't take a shower because I am late for college, I wake up late so I think the response sometimes reminds us to stay healthy and take a break., it can still be done tomorrow.

Individuals who experience stress will show emotional and physical symptoms (Hernawati, N. 2006; Inayatillah, V. 2015). Symptoms that fall into the physical category include, 
headache, heart palpitations, changes in diet, weakness or weakness. This explanation can be seen from the response to the previous question from the interview results, both of them experienced this during the pandemic and did not experience it before the offline learning. Psychologically, each respondent also experienced various emotional and behavioral changes to the pressure and conflict that occurred during the online learning process, such as crying when the task load was quite tiring, felt and was not optimal when studying and doing assignments because of boredom and boredom when go to college. But behind it all, they try to understand the current situation which makes it impossible for direct lectures.

Efforts to manage academic stress experienced by study respondents were mixed. In accordance with the opinion of Maramis (1980) that one of the strategies to stay in a healthy, balanced, and pleasant condition is to increase one's ability to manage stress. Stress can be managed by adjusting to the situation.

Research respondents explained that the various stresses they experience during online lectures do make them feel depressed, and they become more stressed because they are assigned more assignments than usual. But they also realize that they cannot be silent so that even though it is difficult and the road is not easy, they still have to complete the task there is as NS1 said, he will ask his friends if they do not really understand the task given. It is important to have an optimistic mindset, especially during a pandemic. As we know, every day we can see information about Covid cases in Indonesia, so that the possibility of stress is small we must be more optimistic and always be able to be positive.

This online lecture may not be effective for some people because from its implementation, it is imagined that they cannot socialize with one another. As has been explained that in fact students, as said by respondents, they accept the current situation in the world related to covid-19, this is trying to be understood, but sometimes they also feel depressed, and their learning motivation decreases when they are stressed when they face the demands of a lot of assignments and materials that are difficult to understand. As stated by NS1, he felt that his learning motivation had decreased to $50 \%$ during a pandemic. Parents also feel worried when their children take too much energy to do the task, but both sources also say that their parents are very supportive regarding distance learning and doing their best to accompany, and facilitate and remind their children to also stay focused on health.

\section{Conclusion}

Based on the analysis and discussion that has been described, it can be concluded, as follows:

1. The problems of academic stress experienced by study respondents are almost the same and similar. Physically, each respondent experiences all common stress reactions such as headaches and dizziness. Psychologically, each respondent also experiences various emotional and behavioral changes to the pressure and conflicts that occur, such as crying easily, decreased learning motivation and anxiety. . Anxiety usually occurs when they get assignments and when they don't understand the material presented.

2. The stress level of respondents is quite high or increases when they get an assignment from the lecturer.

3. Respondents sometimes do not believe in themselves regarding learning outcomes which they consider to be less than optimal, but both respondents are quite good in terms of self control. Even though it is difficult, they still try to try not to just stand by. The respondent's parents also tried to be supportive even though they were quite worried if their children were too much while doing the task. 


\section{Suggestion}

This research is still very limited because the number of research resource persons is only two people and more in-depth research is needed and also more respondents to find out the Academic Stress Level of Guidance and Counseling Students of Semarang State University.

\section{References}

Atman, Hutomo., Rosada, Dwi. (2020). Analisis Tingkat Stres Mahasiswa terhadap Pembelajaran Daring Pada Mata Kuliah Statistik Bisnis di Pendidikan Vokasi. Jurnal Ilmiah Kependidikan, Vol. XIV, No. 1.

Hasanah, Uswatun dkk. (2020). Gambaran Psikologis Mahasiswa dalam Proses Pembelajaran Selama Pandemi Covid-19. Jurnal Keperawatan Jiwa Volume 8 No 3, Agustus 2020, Hal 299- 306

Saffanah, Fatin., Mardiono, Intan., Dwi, Hersa Y. (2020). Analisis Beban Kerja Mental Mahasiswa saat Perkuliahan Online Synchronous dan Asynchronous menggunakan Metode Rating ScaleMental Effort. Jurnal OPSI Vol 13 No.1 Juni 2020.

Livana, PH dkk. (2020). “Tugas Pembelajaran” Penyebab Stres Mahasiswa Selama Pandemi Covid-19. Jurnal Ilmu Keperawatan Jiwa Volume 3 No 2, Hal 203-208.

Dewanti Eka, Dhea. (2016). Tingkat Stres Akademik pada Mahasiswa Bidikmisi dan Non Bidikmisi Fakultas Ilmu PendidikanUniversitas Negeri Yogyakarta. Skripsi. Universitas Yogyakarta.

Barseli, Mufadhal dkk. (2017). Konsep Stress Akademik Pada Siswa. Jurnal Konseling dan Pendidikan Vol 5, No.3hlm. 143-148.

Fahmi, F. (2011). Hubungan Antara Self-Efficacy dengan Stres Akademik Pada Mahasiswa (Doctoral dissertation, Prodi Psikologi UNIKA Soegijapranata).

Nurmalasari, Yuli., Yustiana, Yusi Riksa, \& Ilfiandra. (2016). Efektivitas Restruksturisasi Kognitif dalam Menangani Stress Akademik Siswa. Jurnal Penelitian Bimbingan dan Konseling, Vol 1, No. 1. 